\title{
PCR法を用いたヌードマウスにおける ヒト転移腫瘍細胞の定量的検出
}

\author{
Specific Detection of Metastasized Human Tumor \\ Cells in Nude Mice by Polymerase Chain Reaction
}

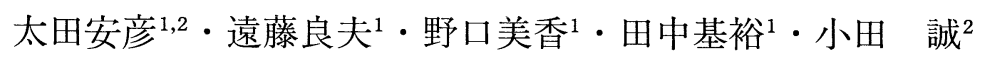

林 義信 $^{2} \cdot$ 清水淳三 $^{2} \cdot$ 渡辺洋宇 $^{2} \cdot$ 佐々木屍磨 $^{1}$

\begin{abstract}
要旨：ヌードマウスにおける転移ヒト腫瘍細胞の特異的且つ定量的な検出方法として, 転移腫 瘍に含まれるヒトに特異的な $\beta$ グロビン遺伝子配列をPCR (polymerase chain reaction) 法により增幅した後, サザンブロット法にて検出および解析する方法を検討した. 移植腫瘍はヒト線維肉腫HT-1080細胞を用いた．実験的転移系では移植後 1 週目より肺 転移が検出され，自然転移系では 5 週目より肺・リンパ節転移を検出できた。肺転移巣 に対する抗癌剤の効果判定は腫瘍細胞移植後 2 週間で得られ, ヌードマウス法がヒト腫 瘍の転移巣に対する治療実験モデルとして応用可能であることが示された。本法は七ト 癌の転移, 浸潤の機構解明および癌転移巣に対する治療法の開発に有用な実験手段にな るものと考える.
\end{abstract}

〔肺癌 33(1) : 51 59, 1993〕

Key words: Metastasis, Nude mouse, Human fibrosarcoma HT-1080,

Polymerase chain reaction

はじめに

実験動物を用いた転移治療モデルの開発は発 展途上にあり，転移癌の化学療法に関する基礎 研究は未だ少ない.転移実験モデルとして 1 ) 確 実にまた恒常性をもって転移が形成されること, 2 ) 簡便なモデル系であることが重要であるが, 治療実験系として応用する場合には加えて 3 ) 定量性，4)迅速性が要求される。本研究では, ヌードマウスにヒト線維肉腫HT-1080細胞を 移植後, PCR (polymerase chain reaction) 法を 用いて転移腫瘍細胞に含まれるヒト $\beta$-グロビ ン遺伝子(576塩基対)に対する特異的増幅反応

1 . 金沢大学がん研究所化学療法部

2. 同第 1 外科
を施行する方法により, 従来の肉眼形態学的観 察では検出不可能な微小転移レベルでの転移七 卜腫瘍細胞の迅速且つ定量的な検出を試みた。

\section{対象および方法}

\section{I 、移植腫瘍細胞と培養}

ヒト線維肉腫培養株HT-1080は, 非働化ウシ 胎児血清とグルタミンを含んだイーグルMEM 培地 (日水製薬社, 大阪) 中において $\mathrm{CO}_{2}$ 濃度 $5 \%, 37^{\circ} \mathrm{C}$ で培養した. EDTA緩衝液を用いて 細胞を剝離した後, 細胞浮遊液を作製し, $27 \mathrm{G} の$ 注射針を用いて $5 \times 10^{6}$ 個 $(0.1 \mathrm{ml})$ を移植した。 移植に用いた腫瘍細胞浮遊液は, トリパンブル 一色素排除試験法により $90 \%$ 以上の生細胞があ 
Fig. 1. Oligonucleotide primers and probe for PCR amplification and their locations in the human $\beta^{-}$ globin gene.

(A) Sequences of oligonucleotide primers and probe used in PCR. (a) The primer Hu $\beta-1$ is complementary to the $(-)$ - strand. (b) The primer $\mathrm{Hu} \beta-8$ is complementary to the $(+)-$ strand. (c) $\mathrm{Hu} \beta-2$ was used as the probe to detect the amplified DNA fragment. (B) Location of the oligonucleotides. The amplified segment is $576 \mathrm{bp}$ with $\mathrm{Hu} \beta-1$ and $\mathrm{Hu} \beta-8$. The downward-pointing codon and filled boxes indicate the $\beta$-globin encoding regions.

Abbreviation : bp, base pairs

\section{A}

a HUB-1: 5-AGAGCCATCTATTGCTTACA-3'

b HUB-8: 5- TATGACATGAACTTAACCAT-3'

c HUB-2: 5-ACACAACTGTGTTCACTAGC-3'

ることを確認した.

II. 実験動物

ヌードマウスは 5 週齢, 此の $\operatorname{ICR}(\mathrm{nu} / \mathrm{nu})$ 系 (日本チャールズリバー社, 厚木)を用いた。マ ウスはspecific pathogen freeの条件下で飼育 し実験に用いた。

\section{III。転移の作製}

実験的転移系としてヌードマウスの尾静脈内 にHT-1080細胞を $5 \times 10^{6}$ 個移植し, 移植後 1 , $2,3,4$ 週目に肺を摘出しDNAを抽出した ${ }^{1)}$. 別途に摘出した肺の一部を10\%ホルマリンにて 固定後, H.E. (hematoxylin and eosin) 染色を施 した標本を作製し, 肺転移の有無を病理組織学 的に追求した。 また, 自然転移系としてHT1080細胞をヌードマウスの右鼠径部皮下に $5 \times$ $10^{6}$ 個移植し，1 $＼mathrm{~ 週 目 ま て ゙ 各 週 毎 に 肺 お よ ひ ゙ ~}$ リンパ節を摘出しDNAを抽出した.

IV 。実験的転移系を用いた肺転移巣に対する治 療実験

ヌードマウス尾静脈内に HT-1080細胞を移 植後, 1 週目にcisplatin (CDDP) $2 \mathrm{mg} / \mathrm{kg}$ また は adriamycin (ADM) $8 \mathrm{mg} / \mathrm{kg}$ を27G注射針を 用いて尾静脈内投与した。抗癌剂投与後 1 およ び 3 週目に肺を摘出し, DNAを抽出した.

V .プライマーおよびプローブ用オリゴヌクレ オチドの作製

PCR法による特異的遺伝子配列の増幅に用 いるプライマーとしてヒト $\beta$-グロビン遺伝子 配列 ${ }^{2)}$ 上, 各20塩基からなるオリゴヌクレオ チドHu $\beta$ - 1 および 8 を, また, PCR増幅 $\beta$-グロ ビン配列を検出するプローブとして $\mathrm{Hu} \beta-2$ を
B

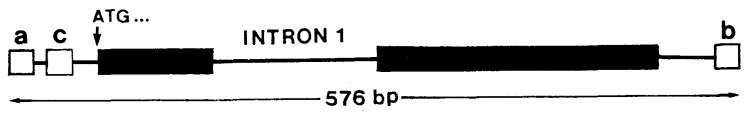

合成した(Fig. 1).なお，これらのオリゴヌクレ オチドはDNA合成装置 PCR イト (Applied Biosystem社, USA)により合成した. プローブ 用オリゴヌクレオチド, $\mathrm{Hu} \beta-2$ はプローブ DNA 13pmolに対し $\left[\gamma^{32} \mathrm{P}\right] \mathrm{ATP} 50 \mu \mathrm{Ci}$ (Amersham社), ポリヌクレオチドキナーゼ緩 衝液 (50mMトリスー塩酸 $\mathrm{pH} 7.6,10 \mathrm{mM}$ 塩化 マグネシウム, $5 \mathrm{mM}$ ジチオトレイール，0.1 $\mathrm{mM}$ スペルミジン及び0.1mM EDTA pH8.0), 10 単位 $\mathrm{T} 4$ キナーゼ (宝酒造社, 京都) 及び滅菌蒸

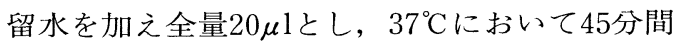
反応させ， 5 ’末端に放射標識を行った。

VI. PCR反応

調整した鋳型DNA $1 \mu \mathrm{g}$ に対しPCR反応緩 衝液 (10mMトリス一塩酸 $\mathrm{pH} 8.3,50 \mathrm{mM}$ 塩化 カリウム, $1.5 \mathrm{mM}$ 塩化マグネシウム), デオキシ リボヌクレオチド混合液 (dATP, dGTP, $\mathrm{dCTP}, \mathrm{dTTP}$ 各 $200 \mu \mathrm{M})$, Therus aquaticus (Taq)DNAポリメラーゼ(Perkin Elmer Cetus 社, USA) 2.5 単位, (+)鎖及び $(-)$ 鎖プライマ 一各 $1 \mu \mathrm{M}$ を加之, 滅菌蒸留水により全量 $100 \mu 1$ に調整した。 反応にはDNA Thermal Cycler (Perkin Elmer Cetus社, USA)を使用し, 熱変 性を $94^{\circ} \mathrm{C}, 2$ 分間, アニーリングを $55^{\circ} \mathrm{C}, 2$ 分 間，DNAの伸長を $72^{\circ} \mathrm{C} ， 2$ 分間とし，これを 1 サイクルとして25サイクル繰り返した。

VII. 増幅されたDNAの検出

増幅後, 各試料は $1.5 \%$ アガロースゲル電気泳 動を施行後, サザン法 ${ }^{3)}$ に準じてナイロンメン ブラフィルター(Hybond-N,Amersham社)に トランスファーした。フィルターはハイブリダ 
Fig. 2. PCR products from the genomic DNA of TH-1080 cells.

(A) Southern analysis of PCR amplification products from serial dilutions of HT-1080 genomic DNA with mouse lung DNA. The PCR products amplified with the primers, $\mathrm{Hu} \beta-1$ and $\mathrm{Hu} \beta-$ 8 could be detected even at concentration of $10^{-5} \mu \mathrm{g}$ of HT-1080 DNA. (B) Plot of the radioactivities of the PCR products from the dilutions of HT-1080 DNA against HT-1080 concentration. Radioactivities in the PCR products hybridized with ${ }^{32} \mathrm{P}$-labeled probe were analyzed using a Fujix Bioimage analyzer. Radioactivity was described in arbitary units (AU ) per $\mathrm{mm}^{2}$.

A

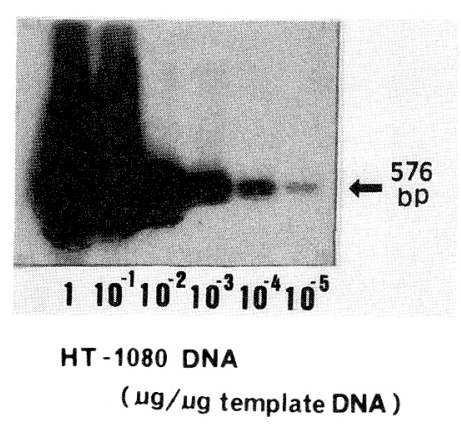

$\mathrm{B}$

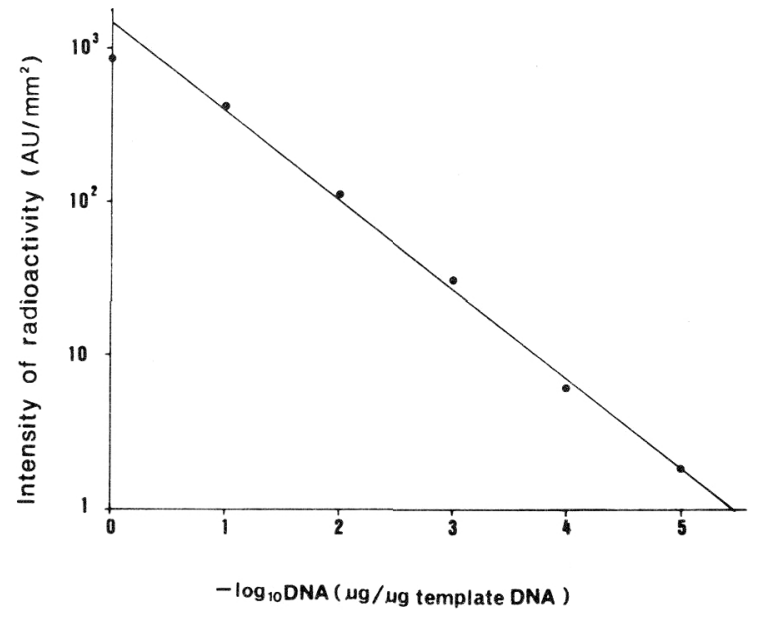

イス緩衝液 $[6 \times \mathrm{SSC}$ (saline sodium citrate), $5 \times$ Denhardt's液 ${ }^{4)}, 0.1 \%$ SDS, $10 \%$ 硫酸デキ ストラン及び $0.1 \mathrm{mg} / \mathrm{ml}$ サケ精子DNA] 中 $43^{\circ} \mathrm{C}$ において1時間のプリハイブリダイゼイション を抢こなった。その後，ハイブリダイズ緩衝液 に対して $0.1 \%(\mathrm{v} / \mathrm{v})$ の $^{32} \mathrm{P}$ 標識プローブを加え， $43^{\circ} \mathrm{C}$ に扔いて16時間八イブリダイゼーションを 行った。ハイブリダイズさせたフィルターは $2 \times \mathrm{SSC}$ 及び $0.1 \% \mathrm{SDS}$ を含む溶液中で $45^{\circ} \mathrm{C}, 15$ 分間の洗浄を 2 回行い,引き続き $0.1 \times$ SSC及び $0.1 \% \operatorname{SDS}$ 含む溶液中で $45^{\circ} \mathrm{C}, 1$ 時間の洗浄 を行った。洗浄後X線フィルム (Kodak社, New York）を用いて室温下12１8時間の感光を行っ たオートラジオグラフィーで解析を行い，さら にバイオイメージアナライザー(富士フィルム 社, 東京)により放射活性の測定を行った。臟器 あたりの移植腫瘍細胞数の算定は, 以下の如く 行った. 正常ヌードマウスの肺DNAで段階希釈 したHT-1080細胞のDNAを用いて, 各PCR反 忍ごとに検量線を作製し(Fig. 2)，検量線に基 づいてー $\log _{10} \mathrm{DNA}(\mu \mathrm{g} / \mu \mathrm{g}$ template DNA)か
らDNA (pg/ $\mu$ g template DNA)を求め, 以下の 公式に基き算出した。

組織あたりの転移腫瘍細胞数 $=$

組織あたりのDNA総量 $(\mu \mathrm{g}) \times$

組織DNA $1 \mu \mathrm{g}$ 西たりのHT-1080 DNA量 $(\mathrm{pg} / \mu \mathrm{g})$

細胞 1 個女たりのDNA量 $(6 \mathrm{pg} / \text { cell })^{5}$

\section{成 績}

I . PCR法の感度

正常ヌードマウスの肺DNAを用いて希䣋し たHT-1080細胞DNAをテンプレートとして25 サイクルのPCR増幅反応を行った結果, サザン 法の後576塩基対の増幅DNA断片が単一のバン ドとして検出でき, PCR法の感度としては $10^{-5}$ $\mu \mathrm{g} ま て ゙ そ の$ 検出が可能であった(Fig. 2)。これ は, 摘出した肺の重量を $200 \mathrm{mg}$ (全DNA量672 $\mu \mathrm{g})$ とした場合, 約 1,120 個の転移腫瘍細胞の検 出に相当した。

\section{II. 転移腫瘍の検出}

1. 尾静脈内移植による実験的肺転移の検出 実験的転移系ではFig. 3Aに示守如く, 移植後 
Fig. 3. Detection of experimental or spontaneous lung metastasis following intravenous or subcutaneous inoculation of HT-1080 cells. (A) Detection of experimental lung metastasis. Lung metastasis could be detected from 1 week after tumor inoculation. Metastasized cells gradually increased from 1 week to 4 weeks after tumor i. v. inoculation. (B) Detection of spontaneous metastasis in lungs and lymph nodes. Both lung and lymph node metastases could be detected from 5 weeks after s. c. inoculation of HT-1080 cells.

A

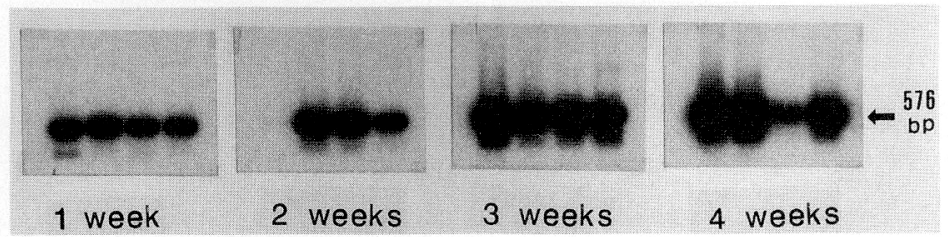

$\mathrm{B}$

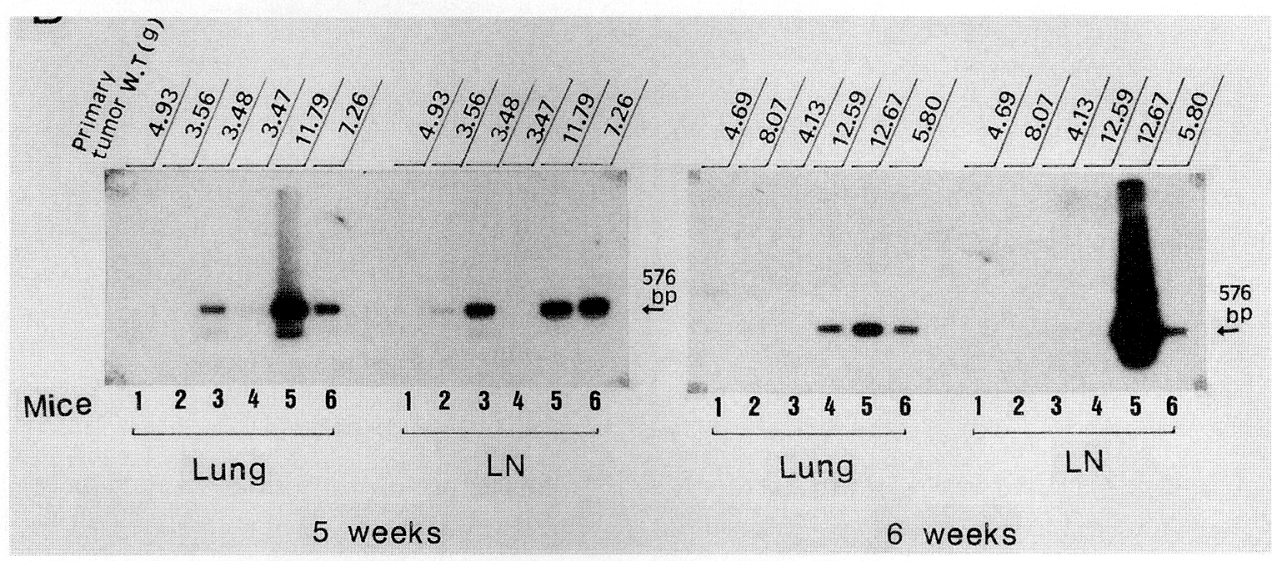

Table 1. Kinetics of growth of HT-1080 cells in mouse lungs after i. v. injection*.

\begin{tabular}{ccccc}
\hline \multirow{2}{*}{$\begin{array}{c}\text { Mouse } \\
\text { No. }\end{array}$} & \multicolumn{4}{c}{ Number of experimental lung metastatic cells $\left(\times 10^{5}\right)$} \\
\cline { 2 - 5 } & 1 week & 2 weeks & 3 weeks & 4 weeks \\
\hline 1 & 4.8 & 0.0 & 127.5 & 163.1 \\
2 & 12.9 & 34.6 & 62.6 & 188.9 \\
3 & 8.2 & 29.6 & 64.7 & 10.4 \\
4 & 8.8 & 9.2 & 42.5 & 73.4 \\
mean \pm S.D. & $8.7 \pm 3.3$ & $18.3 \pm 16.4$ & $77.8 \pm 33.3$ & $109.0 \pm 82.3$ \\
\hline
\end{tabular}

*, HT-1080 cells were inoculated i.v. at $5 \times 10^{6}$ cells mouse.

1 週目より肺転移を確実にとらえることができ た. $5 \times 10^{6}$ 個のHT-1080細胞の移植により, 移 植後 1 週目に扔いて平均約 $8.7 \times 10^{5}$ 個の HT1080細胞が肺より検出された。各週における肺 転移腫瘍細胞数を Table 1に示した.転移腫瘍細 胞数は 1〜 4 週目まで経時的に増加し(Table 1)，転移細胞の肺での転移成立および増殖が確
Fig. 4. Macroscopic findings of experimental lung metastasis at 4 weeks after i. v. inoculation of HT-1080 cells.

Pointing arrows indicate metastatic nodules.

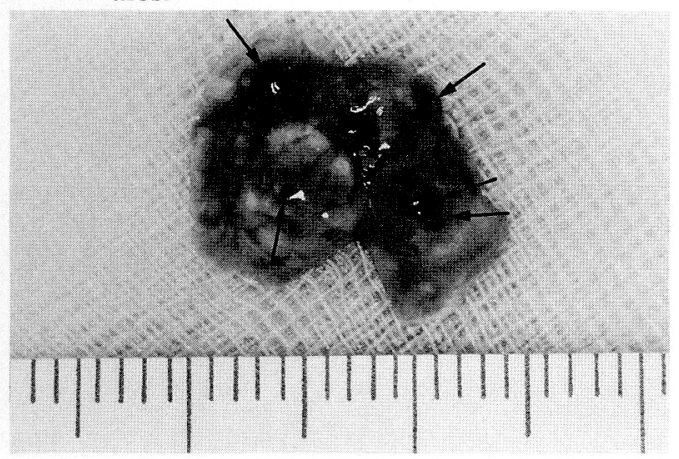

認できた，肉眼上，肺表面に転移結節が認めら れたのは, 腫瘍細胞移植後 4 週目からであった (Fig. 4).この時点でのHT-1080細胞の数は臓 器あたり平均約 $1.1 \times 10^{7}$ 個であった。また, 病理 
Fig. 5. Histological section of experimental lung metastasis at 3 weeks after i. v. inoculation of HT -1080 cells. (H.E. $X$ 40)

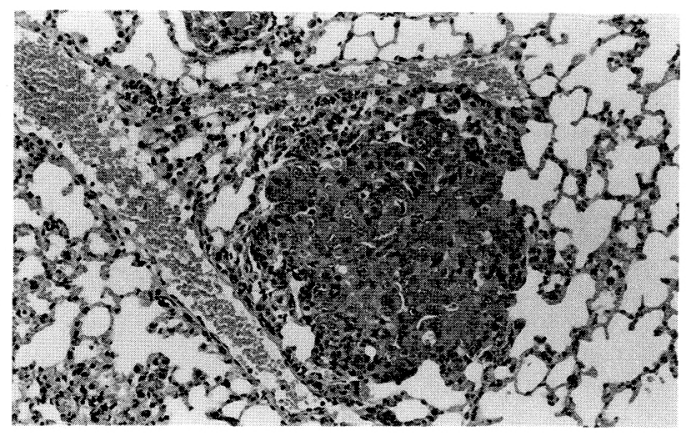

組織上あきらかな肺転移は腫瘍細胞移植後 3 週 目に確認できた (Fig. 5)。この時点での HT1080 細胞の数は臟器あたり平均約 $7.8 \times 10^{6}$ 個で あった。

2. 鼠径部皮下移植による自然肺・リンパ節転 移の検出

自然転移系ではFig. 3Bに示した如く，腫瘍細 胞移植後 5 週目より肺抢よびリンパ節転移をと らえることができた。 5 週日では, 肺 $4 / 6$ (匹)，リンパ節 $6 / 6$ (匹)，6週目では，肺 $3 /$ 6 (匹)，リンパ節 $2 / 6$ (匹)に転移が検出され た。 1 藏器あたりの肺およびリンパ節転移腫瘍 細胞数はTable 2 に示した。

\section{III．転移治療実験}

抗癌剂投与後 1 週目 (腫瘍細胞移植後 2 週目) において, ADM投与群 4 匹中 2 匹に, 未治療群 に比し，PCR増幅DNA断片の明らかな減少が 認放れ，ADMの肺転移巣に対古る治療効果 が示された。また，CDDPを投与した 4 匹のうち 3 匹のPCR増幅DNA断片の減少はみられず, CDDPの治療効果は認められなかった。 ADMと CDDPの肺転移巣に対する転移腫㐭增殖抑制率 はそれぞれ，38.9\%，-60.1\%であった。上よ $\eta$, 腫瘍細胞移植後 2 週間で肺転移巣に対子る 治療効果の判定が可能であった。なお，抗癌剂 投与後 3 週目においては, ADM投与に上る治 療効果は消失し, PCR増幅DNA断片の増加が 認められた。ADM投与群およびCDDP投与群に 扮ける肺転移增殖は未治療群に比し, むし乃増
Table 2. Number $\left(\times 10^{3}\right)$ of spontaneous metastatic cells* in lung and lymph node.

\begin{tabular}{|c|c|c|c|c|}
\hline \multirow{2}{*}{$\begin{array}{c}\text { Mouse } \\
\text { No. }\end{array}$} & \multicolumn{2}{|c|}{5 weeks } & \multicolumn{2}{|c|}{6 weeks } \\
\hline & Lung & $\mathrm{LN}^{* *}$ & Lung & $\mathrm{LN}$ \\
\hline 1 & 0 & 0.6 & 0 & 0 \\
\hline 2 & 0 & 1.9 & 0 & 0 \\
\hline 3 & 20.1 & 12.4 & 0 & 0 \\
\hline 4 & 5.5 & 0.7 & 5.0 & 0 \\
\hline 5 & 94.8 & 10.1 & 19.8 & $1,279.4$ \\
\hline 6 & 612.0 & 41.7 & 3.4 & 7.7 \\
\hline
\end{tabular}

Fig. 6. Effects of anti-cancer drugs on lung metastasis of HT-1080 cells in lung. Anti-cancer drugs were intravenously injected at 1 week after tumor inoculation. Mouse lungs were then dissected at 1 or 3 weeks after chemotherapy.

1 week after chemotherapy

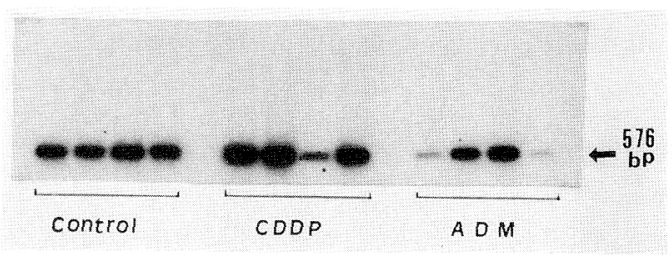

3 weeks after chemotherapy

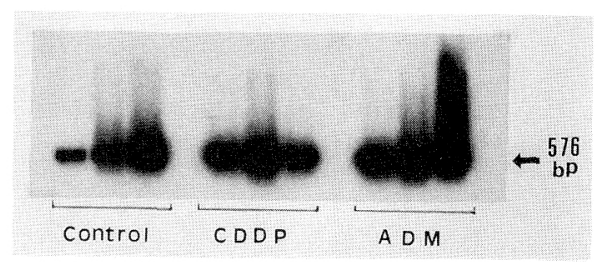

大していた(Fig. 6).

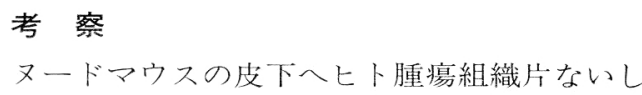
腫湟細胞を移植した場合，皮下に限局した膨張 性の腫瘤を形成することが多く，周囲組織に浸 潤性に增殖することは少ない. 加之て、 ヌード マウスにおける可移植性七ト腫瘍の自然転移率 は，用いた癌種によるばらつきはあるものの， 極めて低く ${ }^{6), 7)}$, ヌードマウスに恒常的に自然転 
移が形成されることは極めて稀とされてきた。 しかし, Ueyamaらは, ヒト䯣膜腫細胞株をヌー ドマウスにて継代培養中, 腫瘍摘出後に肺転移 を認め, 摘出という操作により転移が促進され ることとともに，腫瘍摘出によりマウスの生存 日数が伸びたことを転移成立の原因としてあげ, 観察期間を長くとれば転移率が増す可能性があ ることを指摘した ${ }^{8)}$. 従って, 臟器表面に形成さ れた転移結節数を肉眼的に算定するという現在 の検出方法を改良し, より感度の高い転移検出 法を用いることで，早期に転移を検出できる可 能性がある。今回ヌードマウスに用いた転移腫 瘍の検出法は，Endoらが，受精鶏卵を用いた転 移モデル系の確立を目指して開発したものであ り ${ }^{9)}$ ，転移腫瘍検出の鋭敏性と定量性において 画期的な手法である。従来, 転移の評価は臟器 表面に形成された転移結節数を算定するという 定量性に乏しいものであった，従って，肉眼的 に同定可能な転移結節が形成されるまでの時間 が必要となり，移植腫瘍により多少のばらつき はあるが，ヌードマウスにおけるヒト腫瘍の転 移の評価が可能となるまでには実験的転移系で は $3 \sim 4$ 週間以上，自然転移系では 8 週間以上 を必要とする報告が多い10) 20). 本研究では, PCR法を導入することにより, HT-1080の実験 的肺転移は 1 週目で，肺・リンパ節自然転移は 5 週目で定量的に検出できることを見い出した.

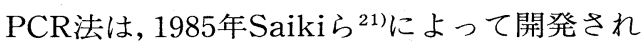
た，微量のテンプレートDNAをもとにin vitro で, 染色体DNA上のある特定の領域を酵素的に 増幅する方法である。即ち，1) DNAの熱変性 ( 2 本鎖DNA断片を 1 本鎖DNA断片にする), 2 ) プライマーのアニーリング, 3 ) DNAポリメ ラーゼによるDNAの合成という 3 段階の行程 を1サイクルとして繰り返すことにより，目的 とする領域の増幅を得ようとするものである。 サイクル数を增やすことで, 理論的にはより高 感度の解析が可能であるが, 目的とするDNA以 外の非特異的な増幅産物が合成されたり，増幅 産物の塩基配列にエラ一が起こる可能性があり, サイクル数の設定には注意を要する. 本研究で は実験中，目的以外の増幅産物を認めたことは
一度もなく，25サイクルという実験条件の設定 に問題はなかったものと考える.

実験的転移系では，あきらかな肺転移は病理 組織上 3 週目より確認されており，1.2週目にお ける転移の検出は微小転移レベルでの転移の評 価といえる. Fidler ${ }^{22)}$ は $^{125} \mathrm{I}-5$-iodo- 2'-deoxyuridineで放射ラベルしたB16メラノーマ細胞 をマウスの静脈内に投与し血流中および各臟器 における腫瘍細胞数の経時的変化を検討してい る。それによると，移植後 24 時間後には約 $1 \%$ の腫瘍細胞しか血流中に生き残ることができず， $2 \times 10^{5}$ 個の生細胞を移植した場合, 肺に認めら れる腫瘍細胞数は減少し続け, 1,2 週目にはそ れぞれ $4.5 \times 10^{2}, 4 \times 10^{2}$ 個に減少しており，同 数の死細胞を移植した場合, 8 時間後には肺に おける腫瘍細胞は消失している。転移が成立寸 る以前ないし初期段階で藏器に捕捉される腫瘍 細胞は極小数であり，且つ転移が成立しない場 合の藏器での停留時間は極めて短いことが予想 されたＢ16メラノーマとHT-1080の動きが同 一とは限らないが, 本研究ではHT-1080細胞を $5 \times 10^{6}$ 個移植し, 1 週目で平均約 $8.7 \times 10^{5}$ 個, 2 週目で平均約 $18.3 \times 10^{5}$ 個と極めて多数の腫 瘍細胞を肺より検出できた。さらに，検出され た転移腫瘍細胞数は各週毎に経時的な増加を示 していたことより, 病理組織的に確認できる以 前の 1 及び 2 週目に検出された腫瘍細胞が単に 肺に捕捉されたものではないと考えた。本法の 検出限界は, $200 \mathrm{mg}$ の肺において約 $1.1 \times 10^{3}$ 個 の転移腫瘍細胞数であることから，より早い時 点での転移の評価も可能であるが, 1 週目以前 の検出においては, 転移成立の有無に関して検 討を加える必要がある.

ヌードマウスにおける移植腫瘍の転移能を左 右する因子として，マウス自体の免疫系を考慮 する必要がある。 T細胞の免疫能が欠如したヌ 一ドマウスにおいてNK細胞が転移抑制に少な から影響を及ぼしていることは，NK活性が 選択的に抑制されたべージュマウスと NK活性 が正常なマウスを用いた転移実験との比較から 既に実証されている ${ }^{23)}$. NK活性の高いヌード マウスでは肺における腫瘍細胞の排除能が高い 
との報告がみられ ${ }^{24)}$, NK活性は，とりわけ脑転 移の抑制に極めて重要な役割を果たしているも のと考えられる。今回，PCR法を転移細胞の検 出法として応用することにより, ヌードマウス の免疫担当細胞としてのNK細胞を抑制せずと も，HT-1080細胞の転移の検出ならびにその定 量的評価は十分可能であった。

腫瘍細胞を移植してから 2 週間という短期間 で転移巣に対する治療効果の判定を下すことが 可能であったことより，新規抗癌剤の開発を目 的とするスクリーニングを含めた癌転移巣に対 する実験化学療法が可能になったといえる。な お，抗癌剤投与後 3 週目において治療効果の消 失と転移増殖を認め，単回の投与ではあったが， 薬剂の投与量が不十分であったことが判明した。 本法を用いて，転移巣に対する薬剂の作用機序 のより詳細な検討をおこなうことにより，転移 巣を抑制する上に有効な抗転移薬剂の選定，投 与量, 投与方法および投与回数を追求すること が可能である.

MTT法 ${ }^{25)}$ 用いたHT-1080細胞に対するin vitroでの感受性試験では, ADMとCDDPの腫 瘍増殖阻止率は臨床投与量での最大血中濃度 (PPC) [ADM : $0.6 \mu \mathrm{g} / \mathrm{ml}$, CDDP : $2.49 \mu \mathrm{g} /$ $\mathrm{ml}]$ の薬剂量で，それぞれ94.4\%，36.4\%であ った。鷄卵法を用いた実験的肝転移巣に対する 感受性試験では, ADM $40 \mu \mathrm{g} / \mathrm{egg}$ ( $8 \mathrm{mg} / \mathrm{kg}$ に 相当), CDDP $5 \mu \mathrm{g} / \mathrm{egg}$ ( $2 \mathrm{mg} / \mathrm{kg}$ に相当)の投 与量にて腫瘍増殖阻止率はそれぞれ $89.5 \%, 5.3$ \%という結果を得ている。従って，原発巣と転 移巣に対する薬剤感受性はヌードマウスと授精
鶏卵ともにADMに感受性が高くCDDPに感受 性が低い点に抏いてよく相関していた。

転移は原発腫瘍から悪性の腫瘍細胞が離脱し, 脈管に侵入し，標的臓器へと移動し，脈管壁間 隙から脈管外へ侵出し，そこで増殖する一連の 現象を総称している。㗖の転移を一連の生 体現象として捕らえ，そこで行われている癌細 胞と宿主との相互作用を明らかにするには，実 用的な転移動物実験モデルの確立が必要である。 微小転移の定量的検出を可能ならしめた本法は, 転移の機序解明および癌転移巣に対する治療法 の開発に有用な手段になるものと考える.

\section{まとめ}

ヒト線維肉腫HT-1080細胞をヌードマウス に移植後, PCR法を用いてヒト $\beta$-グロビン遺伝 子 (576塩基対) に対する特異的増幅反応を施行 し，肺およびリンパ節転移腫瘍細胞の定量的な 検出を試みた。実験的転移系では 1 週目より全 マウスに肺転移が検出され，自然転移系では 5 週目より肺・リンパ節転移が検出された。実験 的転移系を用いた肺転移巣に対する治療実験の 結果は，腫瘍細胞移植後 2 週間で得られた. 又 一ドマウスを用いた転移実験系として本法が適 用可能であり，肉眼による形態学的観察では同 定不可能な微小転移レベルでの定量的な転移の 評洒が可能であった。

なお，本論文の要旨は第32回日本肺癌学会総会 (1991, 滋賀)において発表した。

\section{文}

1) Davis LG, Dibner MD, Battey JF : Basic Methods in Molecular Biology, Elsevier Science Publishing Company, New York, $\mathrm{P} 4,1986$.

2) Lawn RM, Efstratiadis A, O'Connel C, et al : The nucleotide sequence of the human $\beta^{-}$ globin gene. Cell 21:647-651, 1980 .

3) Southern EM:Detection of specific

sequences among DNA fragments separated by gel electrophoresis. J Mol Biol 98 : 503517, 1975.

4) Denhardt DT, Efstratiadis A, O'Connell C, et al: A membranefilter technique for the detection of complementary DNA. Biochem Biophys Res Commun 23:641-646, 1966. 
5) Vendrely R, Vendrely $\mathrm{C}: \mathrm{La}$ teneur du noyau cellulaire en acide désoxyribonucléique à travers les organes, les individus et les espèces animales. Experientia $5: 327-$ 329, 1949.

6) Sharkey FE, Fogh J : Metastasis of human tumors in athymic nude mice. Int J Cancer $24: 733-738,1979$.

7) Riccardi C, Barlozzari T, Santoni A, et al : Transfer to cyclophosphamide-treated mice of natural killer(NK) cells and in vivo natural reactivity against tumors. J Immunol 126 : 1284-1289, 1981.

8) Ueyama Y, Morita K, Ochiai C, et al: Xenotransplantation of a human meningioma and its lung metastasis in nude mice. Br J Cancer 37：644-647, 1978.

9) Endo $Y$, Sasaki $T$, Harada F, et al : Specific detection of metastasized human tumor cells in embryonic chicks by the polymerase chain reaction. Jpn J Cancer Res 81:723-726, 1990.

10) Nicolson GL : Cancer metastasis : tumor cell and host organ properties important in metastasis to specific secondary sites. Biochimica et Biophysica Acta 948:175-224, 1988.

11) Joshi SS, Jackson JD. Sharp JG : Comparison of the growth and metastasis of four human intestinal tumor cell line xenografts. Tumor Biol $10: 117-125,1989$.

12) Sekikawa K, Arends JW, Verstijen CPHJ, et al : Influence of implantation site on growth, antigen expression and metastatic potential of human colonic cancer HT29 and 5583 xenografts in nude mice. Invasion \& Metastasis $8: 238-252,1988$.

13) Alterman AL, Fornabaio DM, Kim YS, et al: The role of intratumor environment in determining spontaneous metastatic activity of a B16 melanoma clone. Invasion \& Metastasis 9:242-253, 1989.

14) Price JE, Daniels LM, Campbell DE, et al : Organ distribution of experimental metastasis of a human colorectal carcinoma injected in nude mice. Clin \& Exp Metastasis 7 :
55-68, 1989.

15) Giavazzi R, Garofalo A: The nude mouse for the study of human colorectal carcinoma. Adv Exp Med Biol(United States) $233: 39-$ 47, 1988.

16) Zimmerman RJ, Gaillard ET, Goldin A : Metastatic potential of four human melanoma xenografts in young athymic mice following tail vein inoculation. Cancer Res $47: 2305-2310,1987$.

17) Kyriazis AP, Dipersio L, Michael GJ, et al : Growth patterns and metastatic behavior of human tumors growing in athymic mice. Cancer Res 38:3186-3190, 1978.

18) Giavazzi R, Campbell DE, Jessup JM, et al : Metastatic behavior of tumor cells isolated from primary and metastatic human colorectal carcinomas implanted into different sites in nude mice. Cancer Res 46:19281933, 1986.

19) Morikawa $\mathrm{K}$, Walker SM, Jessup JM, et al : In vivo selection of highly metastatic cells from surgical specimens of different primary human colon carcinomas implanted into nude mice. Cancer Res 48 : 1943-1948, 1988.

20) Rodolfo M, Balsari A, Clemente C, et al : Tumorigenicity and dissemination of primary and metastatic human melanomas implanted into different sites in nude mice. Invasion \& Metastasis 8:317-331, 1988.

21) Saiki RK, Scharf S, Faloona F, et al : Enzymatic amplification of $\beta$-globin genomic sequences and restriction site analysis for diagnosis of sickle cell anemia. Science $230: 1350-1354,1985$.

22) Fidler IJ : Metastasis : Quantitative analysis of distribution and fate of tumor emboli labeled with ${ }^{125} \mathrm{I}-5$-Iodo-2' -deoxyuridine. J Natl Cancer Inst 45：773-782, 1970.

23) Talmadge JE, Meyers KM, Prieur DJ, et al : Role of NK cells in tumor growth and metastasis in beige mice. Nature $284: 622-624$, 1980.

24) Gorelik E, Wiltrout RH, Okumura K, et al : Role of NK cells in the control of metastatic spread and growth of tumor cells in mice. 
Int J Cancer $30:$ 107-112, 1982.

25) Scudiero DA, Shoemarker RH, Paull KD, et al : Evaluation of a soluble tetrazolium/formazan assay for cell growth and grug sensi- tivity in culture using human and other tumor cell lines. Cancer Res $48: 4827-4833$, 1988.

\title{
Specific Detection of Metastasized Human Tumor Cells in Nude Mice by the Polymerase Chain Reaction
}

\author{
Yasuhiko Ohta ${ }^{1,2}$, Yoshio Endo ${ }^{1}$, Mika Noguchi ${ }^{1}$ \\ Motohiro Tanaka ${ }^{1}$, Makoto Oda ${ }^{2}$, Yoshinobu Hayashi ${ }^{2}$ \\ Junzou Shimizu ${ }^{2}$ Yoh Watanabe ${ }^{2}$ and Takuma Sasaki ${ }^{1}$ \\ 1. Department of Experimental Therapeutics, \\ Cancer Research Institute, Kanazawa University \\ 2. First Department of Surgery, Kanazawa University, School of Medicine
}

In order to develop an assay which is highly sensitive and quantitative, specific detection of a segment of human $\beta$-globin gene in metastasized human tumor cells in nude mice was performed by the polymerase chain reaction (PCR) technique and analyzed by Southern blotting. In this series, we used human fibrosarcoma HT-1080 cells. The results showed that lung metastasis could be detected as positive amplified PCR fragments from 1 week after tumor inoculation in the experimental metastatic model system. On the other hand, both lung and lymph node metastasis could be detected from 5 weeks after tumor inoculation in the spontaneous metastatic model system. In addition, by this method, therapeutic effects on lung metastasis of human tumor in nude mice could be detected within 2 weeks after tumor inoculation. This method will be useful for the elucidation of the mechanism of metastasis or invasion of human tumor cells in experimental animals and should contribute to the development of new chemotherapeutic methods for metastasis. 